\title{
The Natural History of Bulla hydatis Linn.
}

\author{
By \\ N. J. Berrill, \\ Dept. Zoology, McGill University, Montreal.
}

With one Figure in the Text.

Bulla hydatis is a mollusc of relatively rare occurrence in the Plymouth district, although fairly common across the Channel at Roscoff. Intermittent dredging and collecting in the Salcombe estuary over a period of about five years, and some rearing experiments carried out in the department of zoology, University College, London, have afforded some insight into its apparently peculiar distribution and also a few facts of certain general interest.

This tectibranch molluse was recorded during the survey of the Salcombe estuary by the staff of the Plymouth Laboratory in 1902, but it was found only on a spit of sandy gravel on the south shore of the Salstone. Apart from this, it apparently has not been seen except for a few specimens found in the Yealm estuary and one from Jennycliff bay at about the same period. During the succeeding twenty-odd years no record of Bulla was made at all, although there is some evidence that its spawn has been seen though not recognised.

It is accordingly of greater interest that it has been found on almost every visit, winter and summer, made to the Salstone since 1924 ; and it was discovered on each occasion only on the sand spit mentioned above, and below the low-water spring-tide level.

Spawning occurs in June, and a few weeks before that of Oscanius, which is commonly found on the same grounds. The spawn is shown in Figure 1, A, and is usually attached to weed, sometimes to stones, near the datum line. The eggs are approximately $0.2 \mathrm{~mm}$. diameter and two are contained within one capsule; the capsules are arranged in rows along the shorter axis of the jelly (Fig. 1, A and B).

Hatching occurs after two or three weeks when the veliger larvæ have been actively swimming within the capsules for a considerable period. On hatching great variability is seen in their behaviour, some swimming as veligers for a few days although keeping near the bottom, others settling at once to crawl for the rest of their existence. In other words, 
hatching occurs just as the veliger phase is coming to a close, and slight differences in time of hatching may produce great differences in degree of dispersion. However, a large proportion of larvæ are sure to settle immediately, and in this fact lies the explanation of the continuous

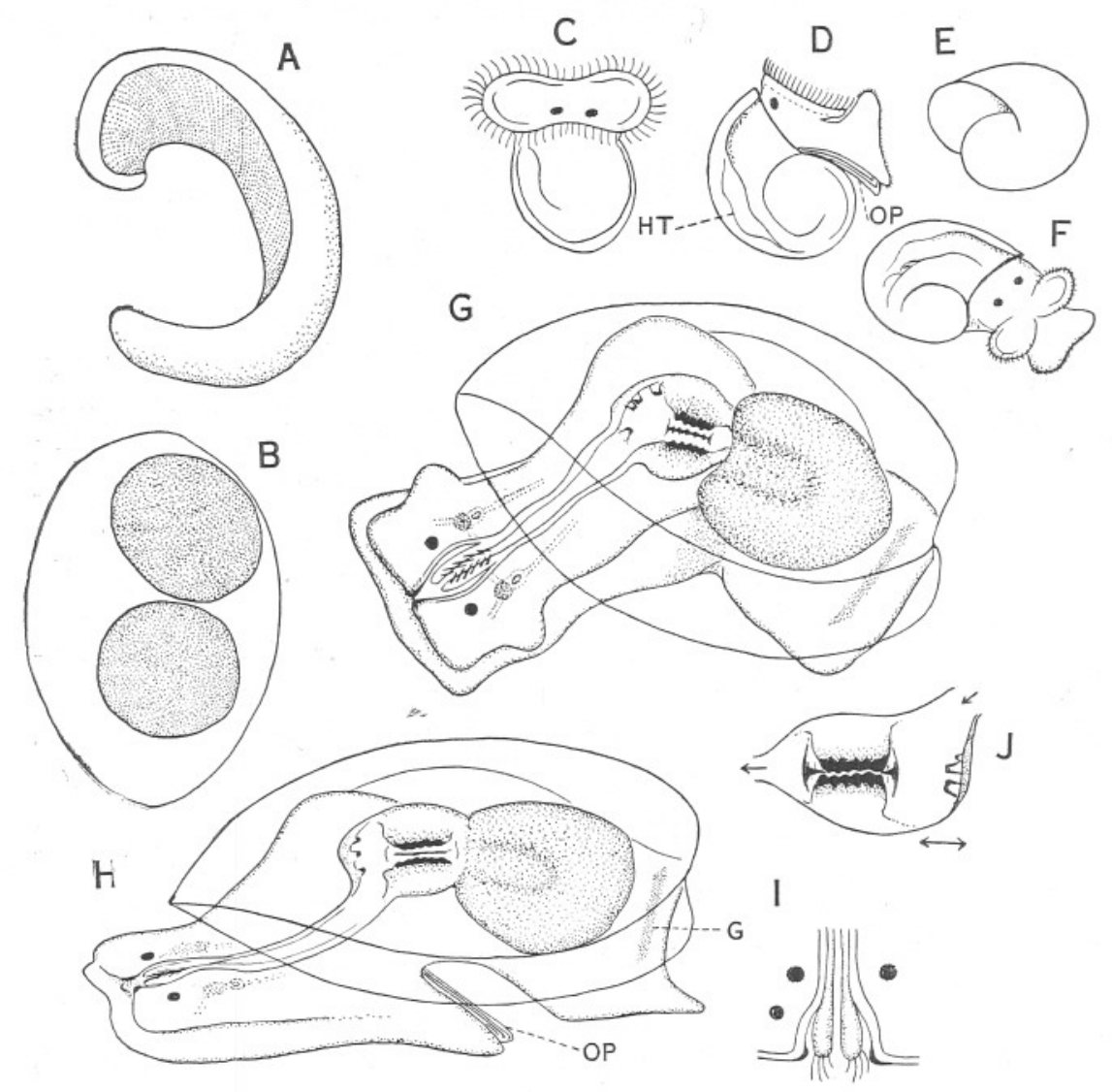

Frg. 1.-A, spawn of Bulla hydatis Linn., about natural size. B, developing eggs within isolated capsule ; capsules are arranged in rows as shown in A. C, D, dorsal and side views of veliger larva at hatching stage. E, stage at which large proportion hatch, when velum somewhat resorbed and larva crawls. F, empty shell of the newly hatched larva. G, H, post-larval forms about two months old, showing gastric mill, larval feeding mechanism, and elongation of shell aperture. I, larval "grab" extended (shown retracted in G), also chitinous lips. J, larger view of gastric mill showing the three teeth, the stoking plates and their range of movement.

occupation of a small sand spit for a recorded period of about thirty years. The apparent absence elsewhere along the south-west coast of England may be due to one of two reasons. The free-swimming veliger phase may be too short for the larvæ to be carried to any other feeding grounds, or, it may occur in most southern estuaries of high salinity 
without having been found. This last is quite possible, for Bulla apparently lives close to the low-water line, spends much of its time burrowing in the muddy sand, and is to be found much more readily by touch than by sight; moreover, but little dredging has been carried out in other estuaries in such very shallow water. Its presence in other districts accordingly is more likely to be indicated by the discovery of the yellow or brownish spawn.

A number of spawn jellies were kept in small aquaria and the hatched larvæ reared until a few, after fifteen months, were about $15 \mathrm{~mm}$. long or about one-third adult size. The chief cause of mortality was the tendency to climb above the water level and dry up before regaining paradise. Frequently a tank was considered to be destitute of survivors when, as time proved, many were ploughing their way beneath the sand, often remaining out of sight for a week or two. The only food obtained by these forms was the sheet of diatoms and algæ encrusting the walls of the aquaria, and these small individuals and also adults seemed to scrape the sides with the radula in a manner quite indiscriminate. Adults opened on capture contained only remains of hydroids and algæ.

Certain observations of some interest were made upon post-larval stages and are illustrated in Figure 1.

Most larvæ upon hatching are able alternatively to swim as veligers or crawl as gastropods; the shell at this time is a simple coil, the opening of which can be closed by the operculum carried on the posterior border of the foot. As post-larval growth proceeds the long ciliated lobes of the velum are resorbed, and the body and shell become much elongated so that the operculum no longer is adapted to the shell opening.

Shortly after the crawling existence commences and until the individual is several millimetres in length, feeding is accomplished by a temporary mechanism. This exists probably because a true radula cannot be encompassed within so small an organism. It is illustrated in Figure 1 and is composed of setæ that project divergently when the buccal mass is extruded; when retracted the setæ close together and are withdrawn, the whole action being that of a grab.

Peristaltic movements convey the food from the buccal cavity to the gastric mill. The exact time and details of the change over to the adult radula mechanism were not determined. The activity of the gastric mill, however, could be seen quite plainly through the transparent tissues. The mill itself consists of three massive teeth, the grinding surfaces of which form an angle of 120 degrees to each other and bear ridges; the whole tooth on removal from the muscle in which it is embedded might. at first sight be mistaken for a small specimen of Chiton. These three teeth fit together and complete a circle; they have two movements, a simple withdrawal from their common centre alternating with their 
mutual approach, and a rocking movement along their long axes after they have approached one another as closely as possible. If there were food in position the one movement would act upon it as a vice, the other as a grinder. If a cross section of the mill be visualised, three radii will be seen corresponding to the spaces between the teeth. In front of the mill is a small crop, the anterior wall of which bears three groups of hard platelike projections. If this wall is pushed toward the mill the three projections fit into the three radii mentioned above ; consequently any food contained within the crop would get pushed accurately into position in the mill. That this does happen is shown by the fact that the anterior wall of the crop pulsates regularly once per second whether or not any food is present, and the wall with the projections it bears acts as a perfect automatic stoking apparatus. Figure 1, G, I, and J, illustrates the above description.

In conclusion a word may be said concerning the significance of hatching enzymes, especially among invertebrates where larval stages are so important.

It has been demonstrated that among the lower vertebrates (Wintrebert, 1926) and the ascidians (Berrill, 1929) proteolytic enzymes are mainly responsible for the process of hatching, and that among the ascidians at least the normal activity of the enzyme is very easily disturbed. Similar enzymes for hatching most certainly occur in many molluses, in particular in Cephalopods such as Loligo and Sepiola, and in Opisthobranchs including Bulla.

The process seems to be the same in these last two groups - a progressive softening of the jelly mass throughout the period of development, and a digestion of the capsule membrane at the end of that time.

Not only are there differences among the gastropods in the time at which hatching occurs but also in the size of the egg, i.e. in the amount of yolk or reserve food it contains. Such yolk may be confined for the most part to the endoderm and in consequence be drawn upon by the whole organism as is the yolk sac in the case of vertebrate embryos; alternatively the yolk may be evenly distributed through all cells; in either case the embryo or larva, compared to embryos developing from smaller eggs, may reach a more advanced stage of development before having to obtain food from without.

The smaller the eggs the sooner they must hatch as larvæ and fend for themselves. At the same time they become subject to a high rate of elimination earlier in life, for until hatching occurs they are relatively safe, a degree of safety comparable to that produced by viviparity in other forms. Moreover, larvæ will be eliminated after hatching at the same rate whether they be large or small. Accordingly any increase in egg size, which necessarily implies a decrease in egg number, will only be of survival 
value if the protected phase of development be prolonged-in other words, if hatching be delayed.

The eggs of most gastropods which possess a prolonged free-swimming veliger phase (possibly of several weeks) have egg volumes much less than that of Bulla (and of the allied form, Scaphander). Since there is no evidence nor suggestion that reduction of yolk has occurred in the group Opisthobranchiata, this smaller egg size may be considered primitive, and accordingly the postponement of hatching in Bulla until the veliger phase is almost over must be considered a direct result of yolk accumulation within the egg.

How such retardation of the hatching process is effected is not known. It is possible that the veliger stage is reached when the embryo consists of a certain number of cells, that is, various sized veligers are composed of approximately the same number of cells but vary in cell size, while hatching enzymes are liberated and become effective when the cells responsible are reduced by successive cleavages to a certain volume. In other words, the larger the egg the larger will be the veliger, but the longer will it be before the hatching enzyme is formed.

In the case of Bulla the importance of the enzyme is obvious. A slight acceleration of its action would result in the liberation of all the embryos as free-swimming larvæ; they would be dispersed over a very wide area but might fail to settle on the parental feeding ground. On the other hand, a slight retardation of its action would confine the veliger phase entirely within the egg capsules, the population of the parental grounds would be maintained and possibly become too dense, and there would be little chance of colonizing new areas; and any changes tending to eliminate the veliger phase from development structurally as well as functionally could take place with impunity.

\section{REFERENCES.}

Allen, E. J., and Todd, R. A. The Fauna of the Salcombe Estuary. Journ. Mar. Biol. Assoc., N.S., Vol. VI., No. 2., p. 151, 1903.

Berrill, N. J. Studies in Tunicate Development. Part 1. General physiology of development in simple ascidians. Phil. Trans. Royal Soc. B., Vol. 218, 1929.

Wintrebert, P. L'Eclosion de la Perche (Perca fluviatilis L.). Compt. Rend. Soc. Biol., Vol. 95. 
